\title{
Comparative performance evaluation of four photovoltaic technologies in saharan climates of algeria: ghardaïa pilot station
}

\author{
Sid Ahmed Tadjer ${ }^{1}$, Abdelhakim Idir ${ }^{2}$, Fathia Chekired ${ }^{3}$ \\ ${ }^{1}$ Electrification of Industrial Enterprises Laboratory, F.H.C.,Université de Boumerdes, 1 Av. de l'Independance, Algeria \\ ${ }^{2}$ Department of Electrical Engineering, University Mohamed Boudiaf of M'sila, Algeria \\ ${ }^{3}$ Solar Equipment Development Unit, Renewable Energy Development Center, Algeria
}

\begin{tabular}{l}
\hline \hline Article Info \\
\hline Article history: \\
Received Aug 10, 2019 \\
Revised Oct 13, 2019 \\
Accepted Oct 27, 2019 \\
\hline Keywords: \\
Comparative study \\
Energetic efficiency \\
Photovoltaic energy \\
Temperature \\
Thin film
\end{tabular}

\begin{abstract}
The aim of this paper is to present an evaluation of the performancerate of four different photovoltaic techniques in the Saharan environment. The purpose of this study is to investigate, analyse, discuss and illustrate the most effective of the different photovoltaic cell technologies (monocrystalline $(m-s i)$, amorphous silicon $(a-s i)$, poly-crystalline silicon $(p c-s i)$ and cadmium telluridethin film $(C d T e-T F))$ installed in Ghardaia which is located in southern ofAlgeria's Sahara desert. In order to choose the most suitable technology in the Saharan climate conditions, the energy values produced by the plant were compared to those found by the PVSYST sizing software. The results show that thin-film and amorphous silicon panels produce low illumination, so they are the best choice for the Saharan environment.
\end{abstract}

Copyright $(0) 2020$ Institute of Advanced Engineering and Science. All rights reserved.

\section{Corresponding Author:}

Sid Ahmed Tadjer,

Electrification of Industrial Enterprises Laboratory,

University of M'HamedBougara of Boumerdes,

1 Av. de l'Independance, 35000 Boumerdes, Algeria.

Email: s.tadjer@univ-boumerdes.dz

\section{INTRODUCTION}

The sun is an almost inexhaustible source of energy that sends to the surface of the earth a radiation that represents each year about 15000 times the current global primary energy consumption [1]. This corresponds to an instantaneous power received of 1 kilowatt peak per square meter $\left(1 \mathrm{kWp} / \mathrm{m}^{2}\right)$ distributed over the entire spectrum, from ultraviolet to infrared. The deserts of our planet receive in 6 hours more energy of the sun that consumes humanity in one year. Algeria has decided to carry onits active participation in the mobilization for the promotion of the environment and sustainable development, and this by promoting these renewable energies which constitute one of the main axes of our energy and environmental policy.

The exploitation of renewable energies by a satisfactory electrification program can supply isolated areas far away from the national electricitygrid. In this context and to develop the solar potential of healthy and inexhaustible energy resources, Algeria has installed a $1100 \mathrm{kWp}$ photovoltaic panel plant in the Ghardaiawilaya, located in the southern Sahara of Algeria. This is to strengthen the existing network on the one hand and to evaluate the behavior of different photovoltaic technologies in the national environment (southern Algeria) on the other.

Different researches and scientists have worked on the performance evaluation of actual behavior of PV modules in outdoor conditions through accurateandreliablemeasurements in a specific geographical location. In [2] the authors conducted an experimental study toevaluate the performance of 12 different types 
of PV modules. An evaluation and comparison performance of PV modules technologies was presented in [3]. Analysis and Monitoring of electrical performance of PV modules was described in [4]. Singh [5] reviewed the influence of geographic location in the electric generation of different photovoltaic module technologies. In [6] the authors evaluated a $(p c-S i)$ modules in Saudi Arabia.

The results indicate that the energy performance is strongly dependent on the operation module temperature. It is useful to monitor the performance of solar PV modules to choose an appropriate technology suitable to improve performance of any future installation of PV system [7], the data analysis provides a summary of performance for comparing PV modules of different technologies, operating under different climates and providing energy for different use [8]. The main objective of this work is to evaluate, analyse and compare theperformance of four PV modules $m-S i, a-S i, p c-S i$ and $C d T e-T F$ of different technologies during an outdoor exposure at the Saharan climate of Algeria.

\section{THE DURATION OF INSOLATION}

Insolation or the duration of sunshine is a temporal parameter characterizing solar radiation. It represents for a day the sum of the time intervals at which the intensity of solar radiation has exceeded a threshold of $100 \mathrm{~W} / \mathrm{m}^{2}$.

\subsection{Potential Insolation}

Potential or theoretical insolation $\left(S S_{0}\right)$ is the value of insolation for the day considered in the absence of atmosphere; it depends only on the geographical position of the place.

$$
S S_{0}(n)=\frac{2}{15} \operatorname{arcos}(-\operatorname{tg} \varphi \cdot \operatorname{tg} \delta)
$$

Where: $\varphi, \delta$ are latitude of the place and the declination of the sun respectively.

\subsection{Solar Times}

The solar time is the time of the day determined by the apparent movement of the Sun, equal to $12 \mathrm{~h} 00$ at the true south. To obtain the legal time, it is necessary to add to it the equation of time, the correction of longitude and possibly summer time. The true noon or solar noon is the local time at which the sun passes the meridian of the observation point and we have:

$$
\begin{aligned}
& T S T=L T-U T+((\Delta t+4 \lambda) / 60)=L T-(U T-(\lambda / 15))+\Delta \lambda / 60 \\
& \Delta t=9.87 \sin 2(0.986 .(J-81))-7.35 \cos (0.986 .(J-81))-1.5 \sin (0.986 .(J-81
\end{aligned}
$$

Where:

TST: (True Solar time) time spotted so that the sun is at the Zenith at noon.

UT : (Universal Time) is a time standard based on Earth's rotation (GMT).

$L T$ : (Local Time) time given by a watch and $\lambda$ is the longitude of the place.

The hour angle $H$ varies from $-180^{\circ}$ to $+180^{\circ}$.

We take: $H>0$ Afternoon, $H<0$ in the morning and $H=0$ Noon TST.

\section{PHOTOVOLTAIC CELLS}

The operation of the $P V$ cell is based on a physical phenomenon called the photovoltaic effect. Figure 1 illustrates the section of a $P V$ cell. Figure 2 shows the equivalent diagram of a real $P V$ cell.

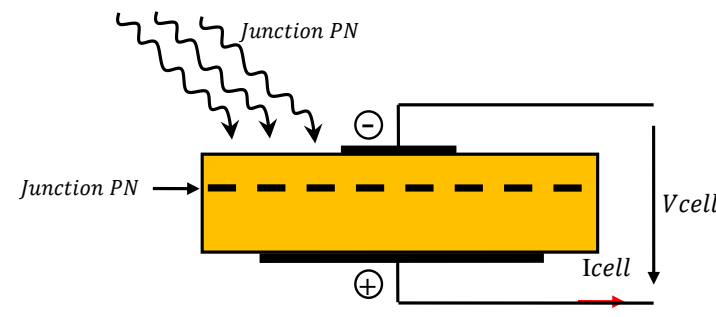

Figure 1. Cross section of a cell

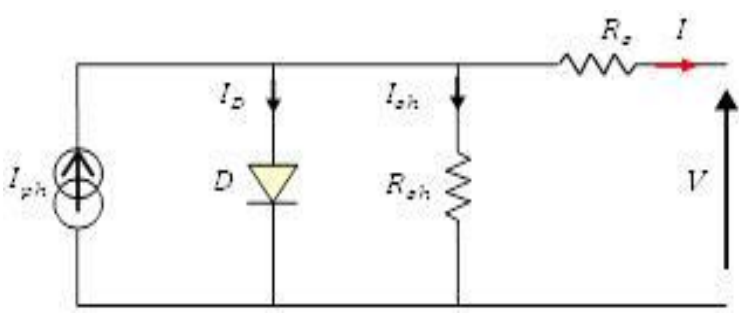

Figure 2. Equivalent diagram of a real $P V$ cell 
This is the most classic model in the literature; it involves a current generator for modeling the incident luminous flux, a diode for the physical phenomena of polarization and two resistors (series and shunt). These resistances will have some influence on the $I-V$ characteristic of the solar cell.

The current of the diode is given by:

$$
\begin{aligned}
& I_{D}=I_{0}\left(e^{\frac{q\left(V+R_{S} I\right)}{A K T}}-1\right) \\
& \text { With }: I_{s h}=\left(\frac{V+R_{S} I}{R_{s h}}\right)
\end{aligned}
$$

The current generated by the $P V$ cell is given by (8):

$$
\begin{aligned}
& I=I_{p h}-I_{D}-I_{s h} \\
& I=I_{p h}-I_{0}\left(e^{\frac{q\left(V+R_{S} I\right)}{A K T}}-1\right)-\left(\frac{V+R_{S} I}{R_{S h}}\right)
\end{aligned}
$$

Where :

$I, I_{0}$ : are current supplied by the cell and saturation current of the diode respectively. $I_{p h}$ : The photo-current depends on the illumination $(\mathrm{G})$.

$q, K$ : are electroncharge and Boltzmann constants; $q=1,602 \cdot 10^{-19} \mathrm{C}$ and $K=1,381 \cdot 10^{-23} \mathrm{Joule} /$ Kelvin $T, A, R_{s}$ : are temperature in Kelvin, Ideality coefficient and Series resistance of the PV cell respectively.

The ideality factor of a $P V$ cell depends on the nature of semiconductor used. The equivalent electric circuit of a solar cell can be put into a block diagram comprising four parameters. The block diagram of $P V$ cell is shown in Figure 3 [11].

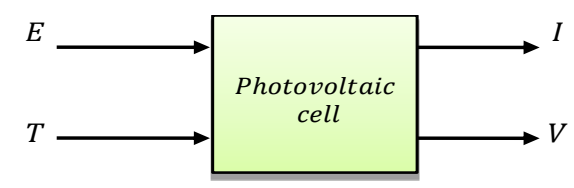

Figure 3. Block diagram of a PV cell

With two input variables:

E, T: are sunshine in the plane of the cell $\left(\mathrm{W} / \mathrm{m}^{2}\right)$ and Cell temperature $\left({ }^{\circ} \mathrm{C}\right)$ respectively. And two output variables:

I, $V:$ are Intensity of current supplied by the cell (A) and Voltage across of the cell respectively.

\section{MATERIALS AND METHODS}

\subsection{Photovoltaic (PV) Modules}

The photovoltaic power station of Ghardaia is located in Oued Nechou about $15 \mathrm{~km}$ from the national road Number. 01(32.4 latitude North, 3.8 $8^{\circ}$ longitude East, 560m altitude). This plant is intended to strengthen the existing network but also to evaluate, analyze and compare theperformance of different photovoltaic module technologies installed in Ghardaia city located in the south of Algeria. Figure 4 shows the satellite image of the plant of Ghardaïa.

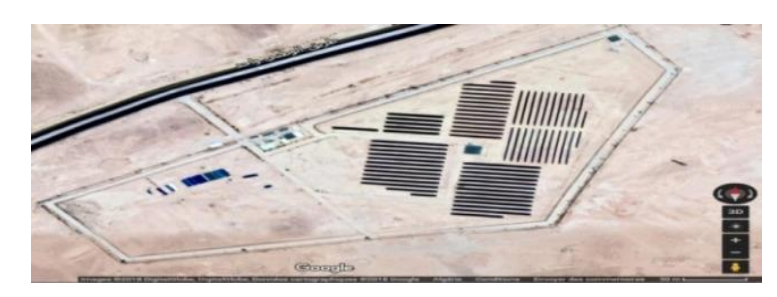

Figure 4. Satellite image of the plant of Ghardaïa 
The PV modules installed in Ghardaia city were composed of four photovoltaic module technologies:mono-crystalline $(m-S i)$, poly-crystallinesilicon $(p c-S i)$, amorphoussilicon $(a-S i)$ and cadmium tellurium thin film $(C d T e-T F)$ with two structures (fixed and motorized). Table 1 shows the main technical features of each solar module technology. The total power of the plant is $1.131816 \mathrm{Wc}$.

Table 1. The Technical Characteristics of the Subfields

\begin{tabular}{ccccc}
\hline Type & Structure & Power $(\mathrm{kW})$ & Number of modules & Number of chain \\
\hline $\mathrm{m}-\mathrm{Si}$ & motorized & 102900 & 420 & 21 \\
& Fixed & 357900 & 1420 & 72 \\
$\mathrm{pc}-\mathrm{Si}$ & motorized & 98700 & 420 & 21 \\
& Fixed & 371300 & 480 & 24 \\
$\mathrm{Cd}-\mathrm{Te}$ & Fixed & 100800 & 1260 & 105 \\
$\mathrm{a}-\mathrm{Si}$ & Fixed & 100116 & 972 & 54 \\
\hline
\end{tabular}

\subsection{Equipment of the Plant}

Figure 5 shows the schematic diagram of connection of the power plant.

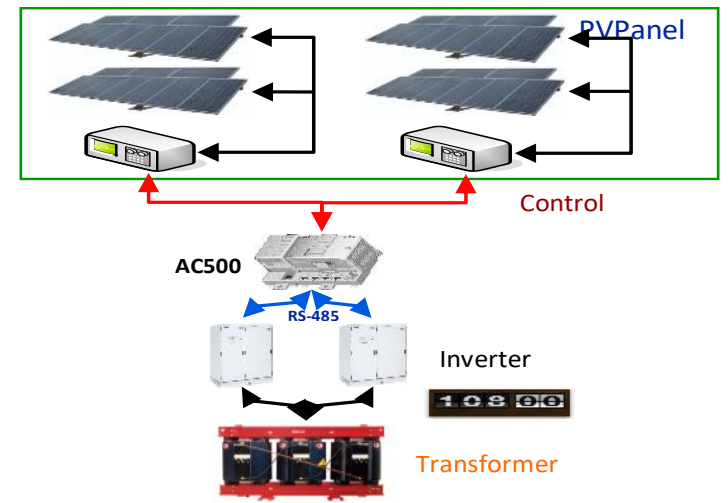

Figure 5. Schematic diagram of connection of the power plant

\subsubsection{Module}

A Four module technologies constitute the central unit for the purpose of experimenting existing technologies in the Saharan environment. PV Solar cells are connected in series to form a PV module chain, which are connected in parallel in a junction box, and that can support and receive up to a max of 16 series.

\subsubsection{Connection Box}

The junction box is the seat of the connections for the wiring of the photovoltaic field. In the box it is realized the parallel of the chains of panels connected. It is attached to the structure or support next to the structure.

\subsection{Box}

Each junction box is connected to a DC box, located near the reference inverter, in the technical building.In the DC box there is the parallel of all the junction boxes of a certain subfield, the output of the box goes directly to the inverter. The DC box is equipped with a couple of fuses for each line that comes from the subfield.

\subsection{Inverters}

The inverters are ASI (Ansaldo Sistemi Industriali) brand type PV8Land PV8M. They are installed in the technical building in the middle of the field. There are eight (8) inverters, one for each subfield. The six $P V 8 L 121$ inverters $(98 \mathrm{kWAC})$ are connected in parallel through a $L V$ switchboard that carries power to a30/0.4kV, 750kVA step-up transformer.In contrast, the two inverters of type PV8M291 (238kWAC), are connected to the two secondary windings of a $30 / 0.27 \mathrm{kV}, 630 \mathrm{kVA}$ transformer.

Figure 6 shows the connection of the eight (08) inverters with the two (02) step-up transformers to transform the energy produced by the field into medium voltage. 


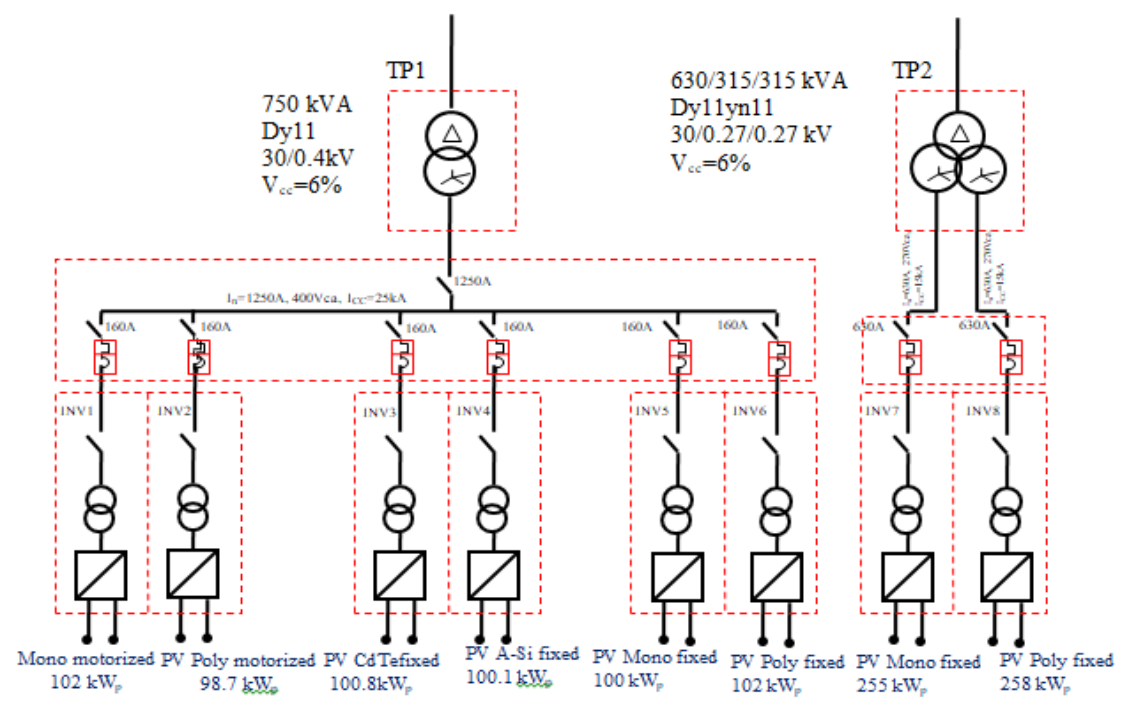

Figure 6. Single wire diagram (inverters /transformers)

\subsection{Transformers}

In the plant there are three transformers: two step-up transformers to transform the energy produced by the field into medium voltage, and an auxiliary transformer to supply the auxiliary services of the plant. The $127 \mathrm{Vdc}$ direct voltage is created through a rectifier system. In the absence of sufficient sun or sunshine, the energy for auxiliaries will be provided by the distribution network to which the plant is connected. For this, at the evacuation station, a bidirectional meter is set up.

\section{RESULTS AND ANALYSIS}

\subsection{Simulation of the Four Technologies and Sizing of a PV System}

The simulation on computers allows the variation of a range of parameters of a system; it becomes interesting to vary these parameters in order to see the behavior of the system for different values. In this work we will simulate the four modules technologies $(m-s i),(a-s i),(p c-s i)$ and $(C d T e-T F)$ installed in Ghardaia pilot station. The pilot station is composed of:

a) The Atersa $A-250 M$ module with $60(m-s i)$ solar cells with a surface of $1.63 \mathrm{~m}^{2}$.

b) The Atersa $A-235 P$ module which comprises $60(p c-s i)$ solar cells with a surface area of $1.63 \mathrm{~m}^{2}$.

c) The First Solar FS -380 module, which has 154 solar cells of $(C d T e-T F)$ with a surface area of $0.72 m^{2}$.

d) The SCHOTT ASI - 103 module with $56(a-s i)$ solar cells with a surface area of $1.449 \mathrm{~m}^{2}$.

Typical power-voltage characteristics are shown in Figure 7. Electrical quantities $P=f(V)$ of the $\mathrm{PV}$ panel field as a function of temperature for $1000 \mathrm{~W} / \mathrm{m}^{2}$ Illumination.

Our goal of the simulation is to see the influence of temperature on the performance of PV modules more than to see the influence of temperature on the characteristics $P=f(V)$. Figure 7 shows that the performance of a PV generator is strongly influenced by the temperature. For low temperature applications, the current and voltage generated by a PV module are assumed to be linear [36]. This allows describing the effect of temperature on performance of a PV module by coefficients. If we denote by $P$ a physical parameter of the module at temperature $T$, we define the corresponding temperature coefficient as follows:

$$
\beta=(P(T)-P(\text { Tref })) /(T-T r e f)
$$

In our case, we took $\mathrm{T}=60^{\circ} \mathrm{C}$, Tref $=25^{\circ} \mathrm{C}$ and we found $P(T)$ and $P($ Tref $)$ of Figures 9. For the calculation of the temperature coefficient we have:

a) for $m-$ si module: $B 1=(224.6-250) /(60-25)=-0.72$;

b) for $p c-$ si module: $B 2=(210.7-235) /(60-25)=-0.69$;

c) for $a-$ si module: $B 3=(72.07-80.48) /(60-25)=-0.24$;

d) for $C d T e-T F$ module: $B 4=(92.29-103.7) /(60-25)=-0.32$. 
The results obtained show that the power losses of $(C d T e-T F)$ modules and $(a-s i)$ module are lower than those of $(m-s i)$ module and $(p c-s i)$ modules. We can say that the performance of a $P V$ module is closely related to the operating temperature of the solar cells and the temperature coefficient. Electrical performance of a $P V$ module usually varies according to the manufacturing technology of the solar cell.

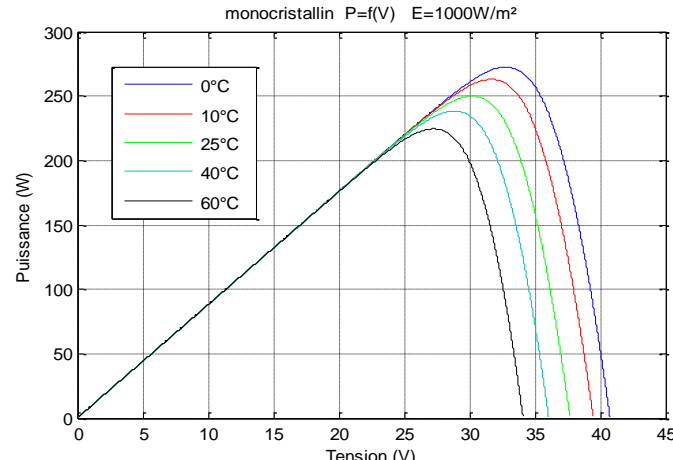

(a)

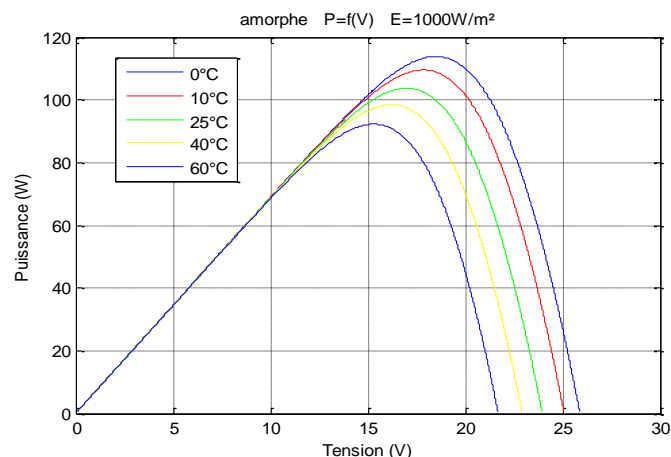

(c)

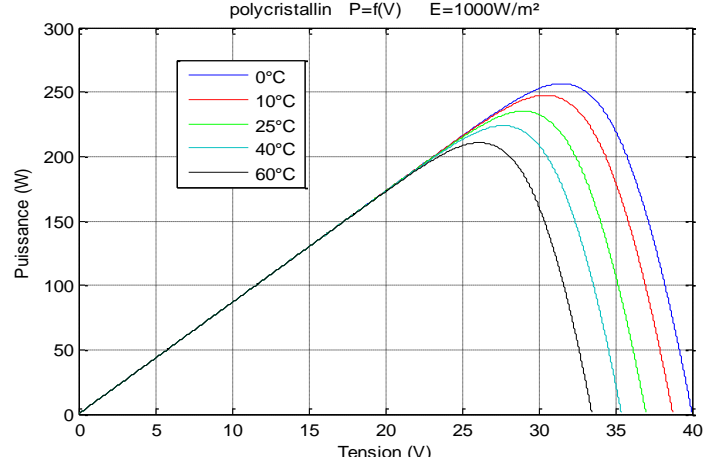

(b)

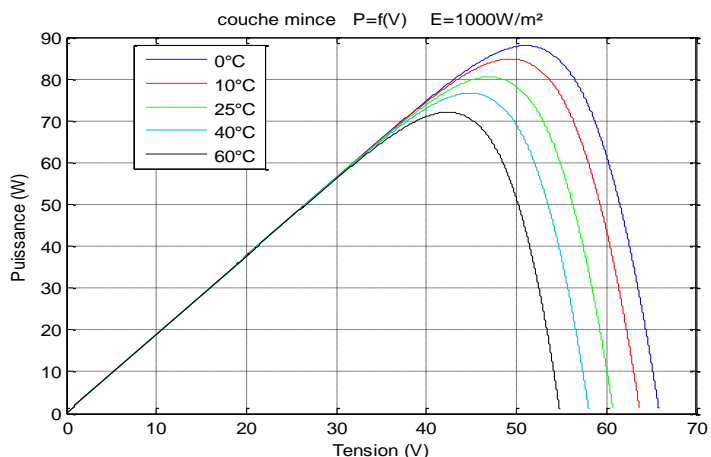

(d)

Figure 7. Different P-V curves for Illumination $=1000 \mathrm{~W} / \mathrm{m}^{2}$ at different temperatures: a) $\mathrm{m}-\mathrm{si}$, b) $p c-s i, c) a-s i, d) C d T e-T F)$

\subsection{Data Analysis}

In order to calculate the monthly energy injected into the network, we have taken the counter index at the evacuation post level during the whole month of September. Figure 8 shows the Daily energy injected to the grid.

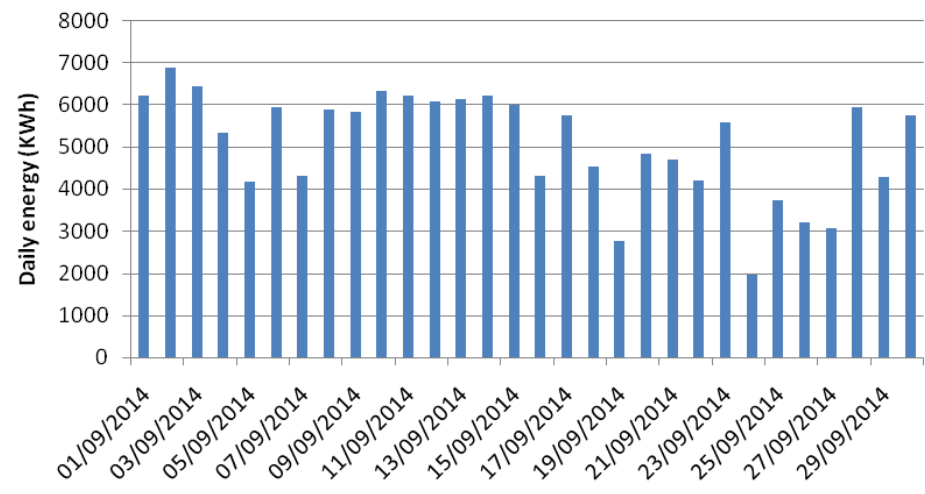

Figure 8. Daily energy injected into the grid 
After anamysing the data, we found that the total amount of energy injected to the grid is $152,63 M W h$ per month. This number is the sum of daily energy produced by the system that are slightly varies throughout the month. Also the energy injected into the grid varies from one day to another with a maximum on the second day of September:

a) The total energy produced in September is $152,63 M W h$;

b) The most productive day is 02 September: $6881,56 \mathrm{kWh}$;

c) The least productive day is 24 September: $1970,31 \mathrm{kWh}$.

The Software used is PVSYS which is a simulation based software used for design and performance analysis of solar photovoltaic power plants. It allows the user to import the meteo data from various sources and analyse grid connected, stand alone, dc grid and pumping systems depending on the specifications of the system and characteristics of its components such as PV module, inverters etc. Table 2 shows the Daily energy injected to the grid.

Table2. Daily Energy Injected to the Grid

\begin{tabular}{cccc}
\hline Type & Structure & Power $(\mathrm{Wp})$ & Energyinjected tothegrid (MWh/month) \\
\hline$m-S i$ & motorized & 102900 & 20,85 \\
& Fixed & 357900 & 54,41 \\
$p c-S i$ & motorized & 98700 & 19,62 \\
& Fixed & 371300 & 54,10 \\
$C d-T e$ & Fixed & 100800 & 16,13 \\
$a-S i$ & Fixed & 100116 & 15,59 \\
& & & Total $=\mathbf{1 8 0 , 7 0 M W h}$ \\
\hline
\end{tabular}

The theoretical total amount of energy injected to the grid is180.705 MWhpermonth. This number is the sum of daily energy produced by the system that are slightly varies throughout the month. Comparing the theoretical total energy with the real energy, we notice a decrease of $15,56 \%$ this difference is due surely to the stains of the panels. One of the contributing factors in the drop of efficiency of solar PV panels in Algeria as well as in other country is the accumulated dust on the panel. The nature of the problem may vary by geographical locations.

In order to calculate the monthly energy produced by these connection boxes, we noted from the data acquisition system installed at the plant, the power produced by each connection box for every 5 minutes. Figure 9 shows that the energy produced by the connection boxes varies from one day to another.

After analysing the data, we found that the total amount of energy injected to the grid is 40,02 $\mathrm{MWh}$ per month. We found that also that:

a) The total energy produced in September by the junction boxes was 40,02 MWh.

b) The most productive day was inthe second of September: 1785,21 $\mathrm{kWh}$.

c) The least productive day is 24/09/2014: 586,88 $\mathrm{kWh}$.

We note that the energy produced injected into the grid and that of the connection boxes are significant on 02 September while they reach low levels on 24 September so we can conclude that the data found at the box level connections used in our study are reliable.

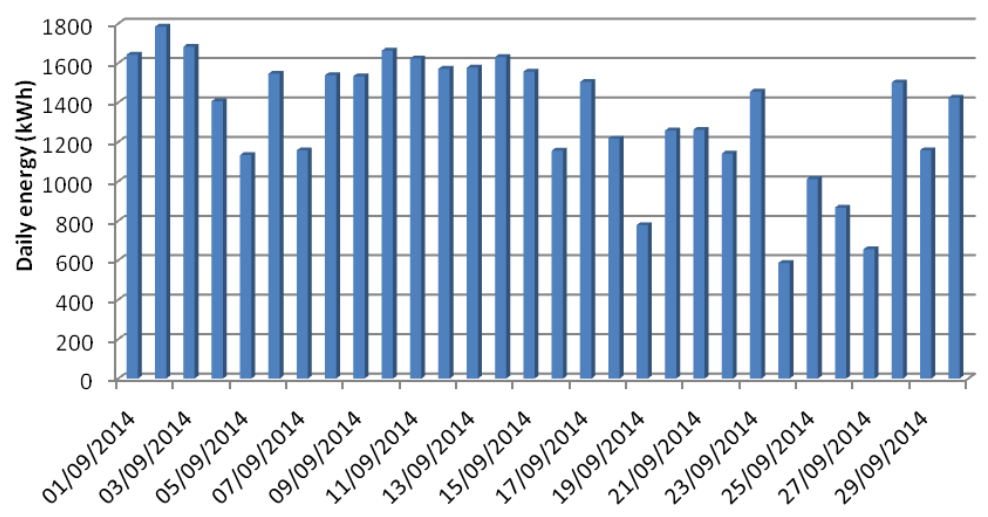

Figure 9. Daily energy in September 


\subsection{Behaviour Study of Four PV Modules Technologies}

In order to study the behaviour and performance comparison of four photovoltaic modules: $m-S i$, $p c-S i, a-S i$ and $C d T e-T F$,we have taken into consideration the most productive day: from 02 September: 1785,21 $\mathrm{kWh}$. Figure 10 shows the characteristics of illumination $(I)$ and temperature $\left(T^{\circ}\right)$ as function of time.

In Figure 10, we observe that the curve of the illumination is ascending from 06: $00 \mathrm{~h}$ to $12: 25 \mathrm{~h}$ where it reaches its maximum with an illumination of $1048 \mathrm{~W} / \mathrm{m}^{2}$, then it goes down to $0 \mathrm{~W} / \mathrm{m}^{2}$ at 18: $45 \mathrm{~h}$. The temperature curve goes down from 00: $00 \mathrm{~h}$ to $06: 45 \mathrm{~h}$ where it reaches its minimum with $T=$ $30{ }^{\circ} \mathrm{C}$ then it rises to reach a maximum temperature of $42.96{ }^{\circ} \mathrm{C}$ to15: $45 h$, and then it goes down to at $32.85^{\circ} \mathrm{C}$ at $00: 00 h$.We noticed that it is a well-lit day with a fairly high temperature. Figure 11 shows the curves of illumination $(I)$ and Power $(P)$ at a junction box for four $P V$ modules technologies.

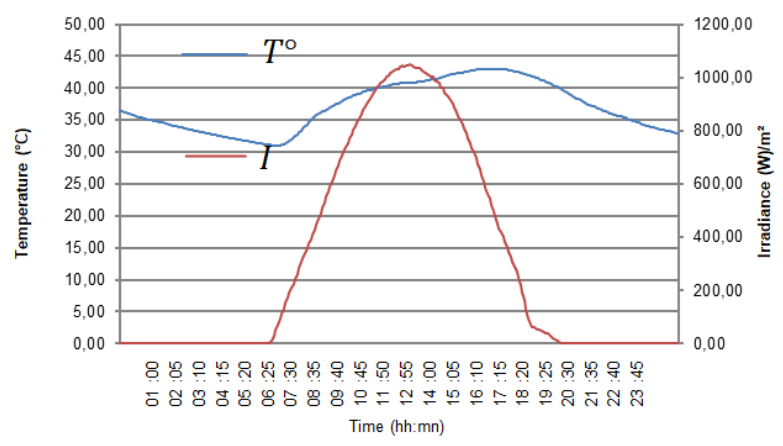

Figure 10. Illumination and temperature as a function of time

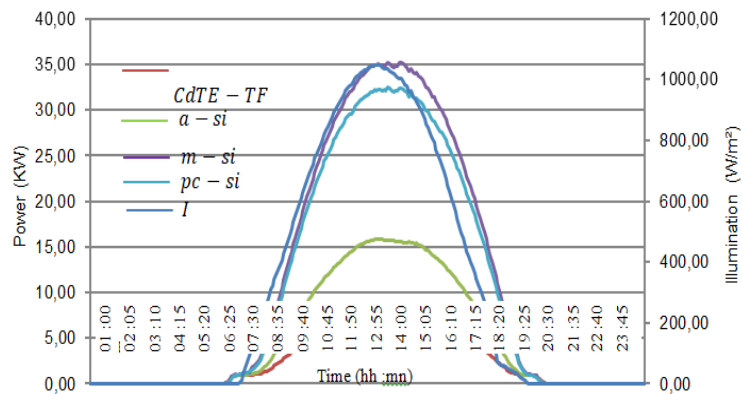

Figure 11. Illumination curves and power at a junction box: $m-S i, p c-S i, a-S i$ and $C d T e-T F$

Figure 11 shows that for all technologies, the power is proportional to the illumination. In order to study the behavior of the four technologies in the Saharan environment, we will integrate power curves produced by a single solar panel of each photovoltaic technology with the following experimental conditions:

a) An illumination of $1048 \mathrm{~W} / \mathrm{m}^{2}$

b) An ambient temperature of $40.84{ }^{\circ} \mathrm{C}$

Therefore according to the (10):

$$
T_{c e l}=T_{a m b}+(N O C T-20) * \frac{E}{80}
$$

With: $T_{c e l}=77.52^{\circ} \mathrm{C}$

NOCT (Nominal Operating Cell Temperature) being the nominal temperature of use of the cells expressed in ${ }^{\circ} \mathrm{C}$ (generally specified in the data sheets of the manufacturer of the module), and $G$ being the illumination in $W / \mathrm{m}^{2}$. If the NOCT value is unknown, a reasonable value of $48^{\circ} \mathrm{C}$ is recommended to represent most of the usual $P V$ modules. Figure 12 shows the power curve produced by $(a-S i)$ panel.

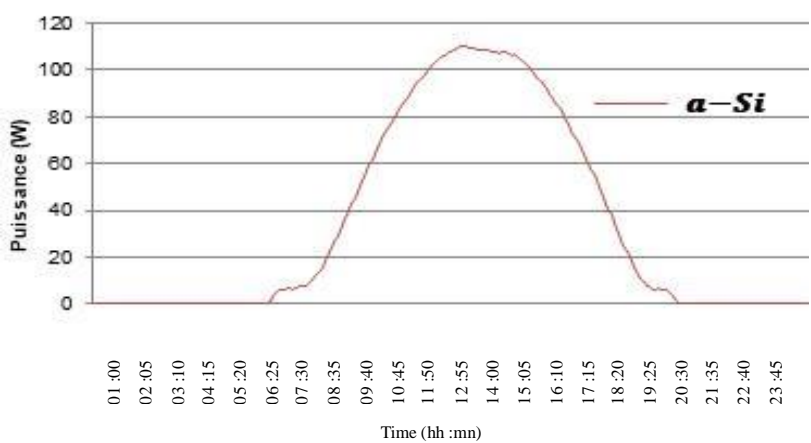

Figure 12. The power curve produced by an amorphous silicon $(a-S i)$ panel 
From Figure 12, we observe that the curve is ascending between 05:30h and 06: $35 \mathrm{~h}$ showing that the power produced by the amorphous silicon $(\mathrm{a}-\mathrm{Si}$ ) panel rises progressively with a production of $6.66 \mathrm{~W}$, from $07: 25 h$ the graph shows a large and fast rise of the curve to reach its maximum at $12: 30 h$ with a maximum power of $109.97 \mathrm{~W}$, then it descends quickly to stabilize for some time from $18: 35 \mathrm{~h}$ with a power of $6.52 \mathrm{~W}$, and finally it goes down to $0 \mathrm{~W}$ at $19: 30 \mathrm{~h}$.

We note that the power produced by the amorphous silicon panel $(a-S i)$ under experimental conditions $\left(I=1048 \mathrm{~W} / \mathrm{m}^{2}\right.$ and $\left.T=77,52^{\circ} \mathrm{C}\right)$ is $109.97 \mathrm{~W}$, whereas in standard conditions $\left(1000 \mathrm{~W} / \mathrm{m}^{2}\right.$ and $25^{\circ} \mathrm{C}$ ) is $103 \mathrm{~W}$ so we find a gain of $6.76 \%$ and we also observe that the amorphous silicon panel produces even at low illumination. We calculate the performance of the amorphous silicon $(a-S i)$ panel under experimental conditions, we find:

$$
\eta \%=\frac{P_{P P M}}{E * S}=\frac{109,97}{1048 * 1,449}=7.24 \%
$$

Figure 13 shows the power curve produced by amonocrystalline silicon $(m-S i)$ panel. Figure 14 shows the power curve produced by apolycrystalline silicon $(p c-S i)$ panel. Figure 14 shows the power curve produced by apolycrystalline silicon $(p c-S i)$ panel.

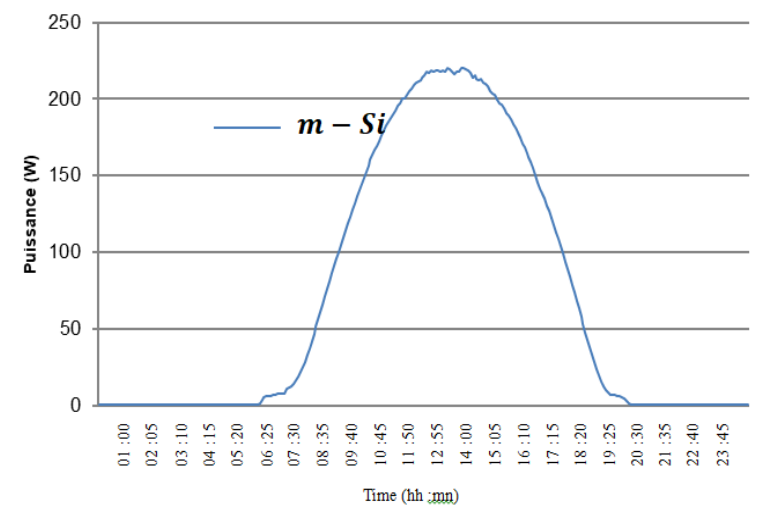

Figure 13. Power curve produced by a monocrystalline silicon $(\mathrm{m}-\mathrm{Si})$ panel

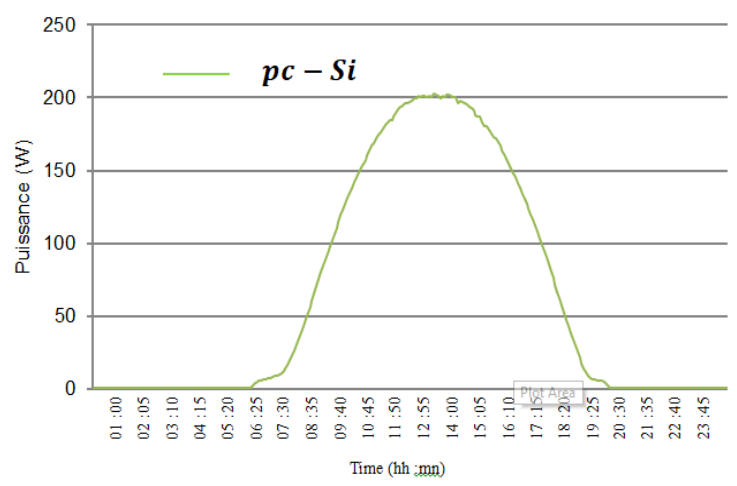

Figure 14. Power curve produced by a polycrystalline silicon $(p c-S i)$ panel

Figure 13 shows that the curve is ascending between 05:30h and 06: $25 h$ showing that the power produced by the monocrystalline silicon $(\mathrm{m}-\mathrm{Si})$ panel rises gradually with a production of $7.25 \mathrm{~W}$, from 07: $25 h$ the graph shows a large and rapid rise of the curve to reach its maximum at $12: 30 h$, with a maximum power of $218.77 \mathrm{~W}$, the latter remains stable for some time and then begins to decrease rapidly to stabilize a second time from 18: $35 \mathrm{~h}$ with a power of $6.87 \mathrm{~W}$ and finally it goes down to $0 \mathrm{~W}$ at $19: 30 \mathrm{~h}$.

We note that the power produced by the monocrystalline silicon panel under experimental conditions $\left(I=1048 \mathrm{~W} / \mathrm{m}^{2}\right.$ and $\left.T=77.52^{\circ} \mathrm{C}\right)$ is $218.77 \mathrm{~W}$ whereas in standardconditions $(1000 \mathrm{~W} /$ $\mathrm{m}^{2}$ and $25^{\circ} \mathrm{C}$ ) is of $250 \mathrm{~W}$ so we find a loss of $12.49 \%$. We calculate the yield of monocrystalline silicon $(m-S i)$ panel under experimental conditions, we find:

$$
\eta_{\%}=\frac{P_{P P M}}{E * S}=\frac{218,77}{1048 * 1,63}=12.80 \%
$$

From Figure 14, we notice that the curve is ascending between 05:30h and 06: $25 \mathrm{~h}$ showing that the power produced by the polycrystalline silicon $(p c-S i)$ panel rises progressively with a production of $6.875 \mathrm{~W}$, from $07: 25 \mathrm{~h}$ the graph shows a significant and fast rise of the curve to reach its maximum at $12: 30 h$, with a maximum power of $201,01 \mathrm{~W}$, the latter remains stable for some time then it begins to decrease quickly to stabilize a second time from $18: 35 \mathrm{~h}$ with a power of $6.25 \mathrm{~W}$ and finally it goes down to $0 W$ at $19: 30 \mathrm{~h}$. We note that the power produced by the polycrystalline silicon $(p c-S i)$ panel under experimental conditions $\left(I=1048 \mathrm{~W} / \mathrm{m}^{2}\right.$ and $\left.T=77,52^{\circ} \mathrm{C}\right)$ is $201,01 \mathrm{~W}$ while in standard conditions $\left(1000 \mathrm{~W} / \mathrm{m}^{2}\right.$ and $\left.25^{\circ} \mathrm{C}\right)$ is of $235 \mathrm{~W}$ so we find a loss of $14.46 \%$. We calculate the performance of polycrystalline silicon $(\mathrm{pc}-\mathrm{Si})$ panel under experimental conditions, we find: 


$$
\eta_{\%}=\frac{P_{P P M}}{E * S}=\frac{201,01}{1048 * 1,63}=11,76 \%
$$

Figure 15 shows the power curve produced by aCdTethin film $(C d T e-T F)$ panel.

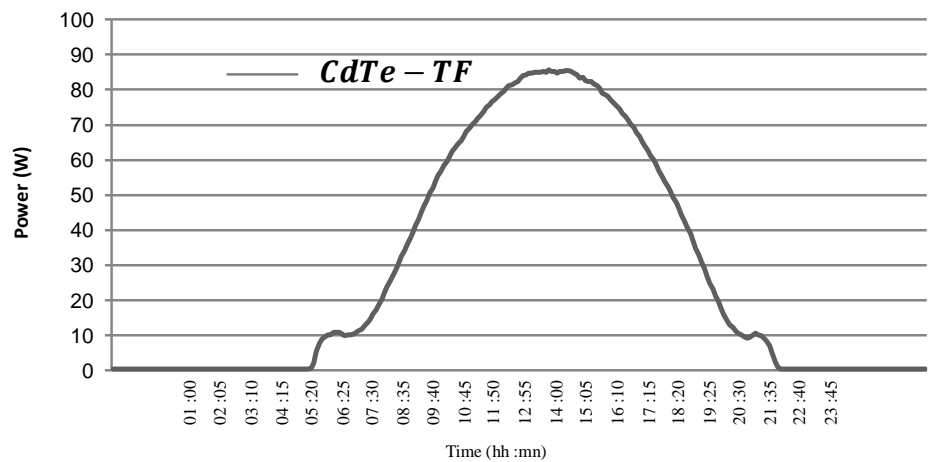

Figure 15. Power curve produced by a Cadium thin film $(C d T e-T F)$ panel

Figure 15 shows that the curve is ascending between 05:30hand 06:25h showing that the power produced by the photovoltaic panel thin film $(C d T e-T F)$ rises progressively with a production of $10.83 \mathrm{~W}$, from 07: $25 h$ the graph shows a significant and rapid rise of the curve to reach its maximum at $12: 30 h$, with a maximum power of $84.92 \mathrm{~W}$, the latter remains stable for some time and then begins to decrease quickly to stabilize a second time from 18: $35 \mathrm{~h}$ with a power of $9.69 \mathrm{~W}$ and finally it goes down to $0 \mathrm{~W}$ at $19: 30 \mathrm{~h}$.

We note that the power produced by the thin-film PV array $(C d T e-T F)$ under experimental conditions $\left(I=1048 \mathrm{~W} / \mathrm{m}^{2}\right.$ and $\left.T=77.52^{\circ} \mathrm{C}\right)$ is $84.92 \mathrm{~W}$ while at standard conditions $\left(1000 \mathrm{~W} / \mathrm{m}^{2}\right.$ and $25^{\circ} \mathrm{C}$ ) is $80 \mathrm{~W}$ so we find a gain of $6.15 \%$ and we also observe that the thin film panel produced at low illuminations.

We calculate the yield of the thin film photovoltaic panel under experimental conditions, we find:

$$
\eta_{\%}=\frac{P_{P P M}}{E * S}=\frac{84,92}{1048 * 0,72}=11.25 \%
$$

To get an idea about the influence of temperature on the performance of each technology, we use data collected during the hottest day of August with sufficient illumination $\left(\right.$ Tcell $=82.69^{\circ} \mathrm{C}$ and $I=$ $928.24 \mathrm{~W} / \mathrm{m}^{2}$ ). Table 3 below shows the behavior of different technologies to:

a) Standard conditions $\left(\mathrm{T}=25^{\circ} \mathrm{C}\right.$ and $\left.\mathrm{I}=1000 \mathrm{~W} / \mathrm{m}^{2}\right)$;

b) Experimental conditions "1" during the most productive day in September $\left(T=77.52^{\circ} \mathrm{C}\right.$ and $I=$ $\left.1048 \mathrm{~W} / \mathrm{m}^{2}\right)$

c) Experimental conditions "2" during the hottest day with sufficient illumination in August $\left(T=82.69^{\circ} \mathrm{C}\right.$ and $I=928.24 W / m^{2}$ ).

\begin{tabular}{|c|c|c|c|c|c|c|}
\hline \multirow[b]{2}{*}{ Terms panel } & \multicolumn{2}{|c|}{ Standard conditions } & \multicolumn{2}{|c|}{ Experimental conditions "1" } & \multicolumn{2}{|c|}{ Experimentalconditions "2" } \\
\hline & $\mathrm{P}(\mathrm{W})$ & $\eta(\%)$ & $\mathrm{V}(\%)$ & $\eta(\%)$ & $\mathrm{V}(\%)$ & $\eta(\%)$ \\
\hline$m-S i$ & 250 & 15,35 & $-12,49$ & 12,80 & $-48,45$ & 8 \\
\hline$p c-S i$ & 235 & 14,43 & $-14,46$ & 11,76 & $-54,11$ & 8,40 \\
\hline$C d T e-T F$ & 80 & 11,11 & $+6,15$ & 11,25 & $-0,91$ & 11,86 \\
\hline$a-S i$ & 103 & 7,10 & $+6,76$ & 7,24 & $-1,03$ & 7,57 \\
\hline
\end{tabular}

Table 3. Behavior of Different Technologies According to the Conditions

With

$V$ :is the variation of the power of the panel under experimental conditions compared to standard conditions.

We note that the performance under standard conditions of $p c-S i$ panels is greater than that of $(a-$ $\mathrm{Si})$ and $(\mathrm{CdTe}-\mathrm{TF})$ panels.At experimental conditions "1" $\left(T=77.52{ }^{\circ} \mathrm{C}\right.$ and $\left.I=1048 \mathrm{~W} / \mathrm{m}^{2}\right)$, a gain in power at the level of the amorphous silicon $(a-s i)$ and thin film $(C d T e-T F)$ panels $(+6,76$ and $+6,15$ respectively)(see table 3$)$ while at the level of the crystalline silicon $(m-s i$ and $p c-s i)$ panels we find a power loss $(-12,49$ and $-14,46$ respectively)(see table 3$)$. Under the same conditions, we also notice 
that the efficiency of the amorphous silicon $(a-s i)$ and thin film $(C d T e-T F)$ panels rises compared to the yield in standard conditions, on the other hand the yield of the crystalline silicon $(\mathrm{m}-s i$ and $p c-s i)$ panels decreases with respect to the yield found under the conditions standards.

At experimental conditions "2" $\left(T=82.69^{\circ} \mathrm{CandI}=928.24 \mathrm{~W} / \mathrm{m}^{2}\right)$, we observe significant power losses in the crystalline $(\mathrm{m}-s i$ and $p c-s i)$ panels whereas those of the amorphous silicon $(\mathrm{a}-s i)$ and thin-film $(C d T e-T F)$ panels are significantly less important. Under the same conditions, the efficiency of the amorphous and thin-film panels is higher than the yield under standard conditions and experimental conditions "1", and the yield of crystalline silicon panels decreases significantly compared to yield found at standard and experimental conditions " $1 "$.

\section{COMPARATIVE STUDY}

In order to study the performance comparison of four photovoltaic modules: $m-S i, p c-S i, a-$ $S i$ and $C d T e-T F$, it is necessary to know how many $k W h$ is likely to deliver $1 k W p$ of photovoltaic panels. Table 4 below shows the energy produced by $K W c$. Figure 16 shows the classification of four technologies: $m-S i, p c-S i, a-S i$ and $C d T e-T F$ in relation of energy produced by $1 K W c$.

Table 4. The Energy Produced by $k W c$

\begin{tabular}{cccccc}
\hline Series & Type & Structure & Power $(\mathrm{kWp})$ & Energy $(\mathrm{kWh})$ & $\mathrm{kWh} / \mathrm{kWp}$ \\
\hline 1 & CdTe-TF & Fixed & 07,680 & 1511,83 & 196,85 \\
4 & $\mathrm{a}-\mathrm{Si}$ & Fixed & 14,832 & 2728,08 & 183,93 \\
5 & $\mathrm{~m}-\mathrm{Si}$ & Fixed & 40,000 & 6854,45 & 171,36 \\
6 & $\mathrm{pc}-\mathrm{Si}$ & Fixed & 37,600 & 5548,51 & 147,56 \\
\hline
\end{tabular}

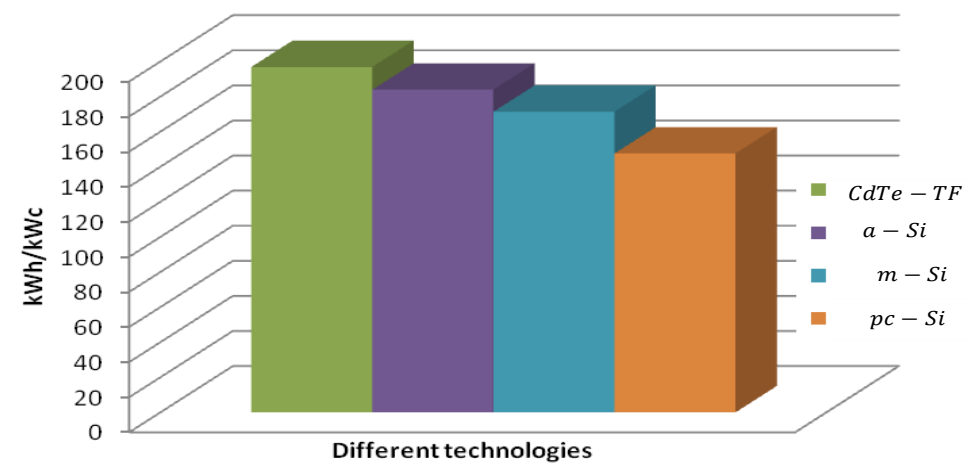

Figure 16. Classification of technologies in relation to the energy produced by $1 \mathrm{kWc}$

According to Table 4 and Figure 16, the ranking of technologies in relation to the energy produced by $1 \mathrm{Kwc}$ is as follows:

a) Cadmium tellurium thin film(CdTe - TF)on fixed structure: $196.85 \mathrm{kWh} / \mathrm{kWp}$,

b) Amorphous silicon $(a-s i)$ on a fixed structure: $183.93 \mathrm{kWh} / \mathrm{kWp}$,

c) Monocrystalline silicon $(m-s i)$ on fixed structure: $171.36 \mathrm{kWh} / \mathrm{kWp}$,

d) Polycrystalline silicon $(p c-s i)$ on fixed structure: $147.56 \mathrm{kWh} / \mathrm{kWp}$.

So Cadmium tellurium thin film $(C d T e-T F)$ and amorphous silicon $(a-s i)$ panels are more efficient than crystalline modules $(m-s i$ and $p c-s i)$.

\section{CONCLUSION}

In this article we have described the plant in detail in order to be able to study the behaviour of the various technologies in the desert environment during the month of September, and for that we have noted the energy values produced by the plant and we have compared them to those found by the PVSYST sizing software, then we performed the energy calculations produced by each technology and we compared the results found to deduce the one that is the most efficient. The energy yield delivered by different types of photovoltaic modules technologies is a key consideration in the selection of appropriate $P V$ technologies. 
Power output of different $P V$ modules is not only affected by its nominal power rating, but also affected by weather parameters such as temperature and irradiation and modules mounting system.

In this article a comparative performance evaluation of four photovoltaic technologies $(m-S i$, $p c-S i, a-S i$ and $C d T e-T F)$ in Saharan climates of Algeria has been studied with the aim to better understand their behavior in real operating conditions. Thus, it can be concluded that the performance of the system used in this study shows that cadmium tellurium thin film $(C d T e-T F)$ and amorphous silicon $(a-$ si) modules proved to produce relatively high yields, so they are the best choice for the Saharan environment. Hence, in practice, dust must be removed from the surface of solar PV panel in order to ensure highest performance, given the fact that it is still a costly form of energy source and the short lifespan it has.

\section{REFERENCES}

[1] N. Madjoudj and M. Dahmane, "Alliance of renewable energy resources for sustainable building-algerian case", Revue des Energies Renouvelables, Vol. 20 No. 3, pp. 483-496, 2017.

[2] M. Schweiger, U. Jahn and W. Herrmann, "Factors affecting the performance of different thin-film PVtechnologies and their impact on the energy yield, 2011, “ in Proceeding of European Photovoltaic SolarEnergy Conference and Exhibition (EU PVSEC) (Germany, 2011), pp. 3640-3645.

[3] C. Cornaro and D. Musella, "Performance analysis of PV modules ofvarious technologies after more than one year of outdoor exposure in Rome," in Proceedings of the III international conference on appliedenergy, 2011.

[4] "IEC 61724 Std. Photovoltaic System Performance Monitoring-Guidelines for Measurement, Data Exchange and Analysis." IEC, 1998.

[5] Singh G. "Solar power generation by PV (photovoltaic) technology: a review".Energy 2013.

[6] Rehman S, El-Amin I. "Performance evaluation of an off-grid photovoltaic system in Saudi Arabia“. Energy, 2012.

[7] C. Cañete, J. Carretero, and M. Sidrach-de Cardona, "Energy performanceof different photovoltaic module technologies under outdoor conditions,"Energy, vol. 65, pp. 295-302, 2014.

[8] M. E. Basoglu, A. Kazdaloglu, T. Erfidan, M. Z. Bilgin, and B. çakır,"Performance analyzes of different photovoltaic module technologiesunderizmit, kocaeli climatic conditions," Renewable and SustainableEnergy Reviews, vol. 52, pp. 357-365, 2015.

[9] D. Polverini, T. Huld, R. Kenny, “Effects of operating conditions on thin-film amorphous and microcrystalline silicon module performance", In: Proceedings of the 26th European photovoltaic solar energy conference, 2009.

[10] T. Huld, R. Gottschalg, H. Beyer, M. Topic, "Mapping the performance of PV modules, effects of module type and data averaging", Sol Energy, 2010.

[11] C. Yu, J. Chai, S. Han'Z. Liu'X. Li'J. Yao, 'Field performance evaluation of various crystalline silicon photovoltaic technologies in Pingshan, China", Energy Reports, Vol.5, pp. 525-528, 2019.

[12] C. Cornaro, D. Musella, D.Chianese, G. Friesen, S. Dittmann, "Outdoor PV module performance comparison at two different locations",Proceedings of the AMSE-ATI-UIT2010 Conference on Thermal and Environmental Issues in Energy Systems, 16-19 May, Sorrento, Italy, 2010.

[13] T. Minemoto, S. Nagae, H. Takakura, "Impact of spectral irradiance distribution and temperature on the outdoor performance of amorphous Si photovoltaic modules", SolarEnergyMaterials\& Solar Cells, vol. 91, 2007.

[14] I. Romero-Fiances, E. Muñoz-Cerón, R. Espinoza-Paredes, G. Nofuentes, J. de la Casa, “Analysis of the Performance of Various PV Module Technologies in Peru", Energies, vol 12, 2019.

[15] A. Bennouk, A. Nejmi and M. Ramzi, 'ALyapunov Based Approach to Enchance Wind Turbine Stability', Indonesian Journal of Electrical Engineering and Informatics, Vol.5, pp. 145-154, 2017.

[16] K. Kumar, M. A. Ansari, "Evaluation of Power Management Strategy for Renewable Microgrid System, Indonesian Journal of Electrical Engineering and Informatics, Vol. 6, pp. 133-142, 2018.

[17] Guenounou A, Malek A, Aillerie M. "Comparative performance of PV panels of different technologies over one year of exposure: application to a coastal Mediterranean region of Algeria“. Energy Convers Manage, Vol 140, 2016.

[18] Mussard, M. and M. Amara, "Performance of solar photovoltaic modules under arid climatic conditions: A review“. Solar Energy, 2018. 174: pp. 409-421.

[19] Guechi A, Chegaar M, Aillerie M. "Environmental effects on the performance of nanocrystalline silicon solar cells". Energy Procedia 2012; 18: 1611-23.

[20] "SMA Solar Technology AG, Performance ratio Quality factor for the PV plant", 2019.

[21] Kahoul N, Houabes M, Sadok M. "Assessing the early degradation of photovoltaic modules performance in the Saharan region“. Energy Convers Manage, 2014;82:320-6.

[22] A. Balaska, A. Tahri, A. B. Stambouli, F. Tahri and T. Oozeki, "Comparative performance evaluation of different technologies of photovoltaic modules in Algeria," 2016 7th International Renewable Energy Congress (IREC), Hammamet, 2016, pp. 1-5.

[23] M. Mostefaoui, A. Ziane, A. Bouraiou, and S. Khelifi, "Effect of sand dust accumulation on photovoltaic performance in the Saharan environment: southern Algeria (Adrar)," Environmental Science and Pollution Research, 2018.

[24] Bouraiou et al., "Experimental investigation of observed defects in crystalline silicon PV modules under outdoor hot dry climatic conditions in Algeria," Sol. Energy, vol. 159, 2018.

[25] Carr AJ. "A detailed performance comparison of PV modules of different technologies and the implications for PV system design methods“. Phd Thesis of Murdoch University, Western Australia; 2005.

\footnotetext{
Comparative performance evaluation of four photovoltaic technologies in Saharan... (Sid Ahmed Tadjer)
} 


\section{BIOGRAPHY OF AUTHORS}

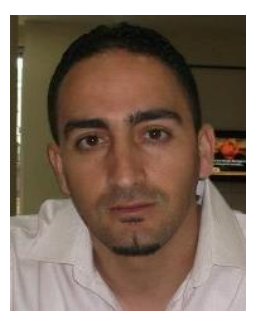

Sid Ahmed TADJER was born in Reghaia, Algiers, Algeria. He received his B.S, M.S and doctorate degreesin Electromechanical engineer, industrial electrical equipment and Electrical from University M'Hamed Bougara of Boumerdes FHC-UMBB, Algeria, in 2003, 2008 and 2016 respectively. He is currently working as Associate Professor in Automation department of processes and electrification. His current research interests include the modeling and simulation of power electronic converters and renewable energy as well as the integration of smart grids.

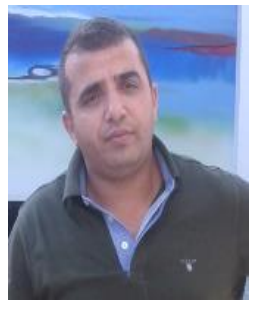

Abdelhakim IDIRwas born in Ait Smail-Bejaia, Algeria. He received his B.S and M.S degrees in control from Bejaia University and Setif University in 2003 and 2006 respectively. He received his doctorate and HDR degrees in electrical engineering from University M'Hamed Bougara of Boumerdes, Algeria, in 2015 and 2018, respectively. From November 2008 to July 2019, he was a Lecturer in the Department of Electrical Engineering, Boumerdes University, Algeria. He joined Mohamed Boudiaf University of M'Sila, Algeria in 2019 where he is an associate Professor in the department of Electrical Engineering. His current research interests include the modeling, simulation and control of fractional systems, fractional PID control, AC drives and renewable energy.

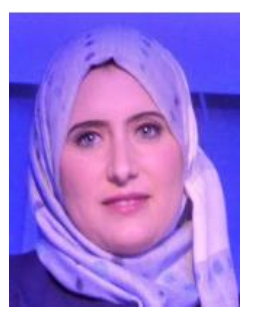

Fathia CHEKIRED is a scientific researcher in Solar Equipment Development Unit/Renewable Energy Development Center (CDER) since 2009. She received his degree in Electronic Engineering from Jijel University (Algeria) in 2006 and his MSc degree in electronics (Option: Solar Electricity) and her PhD from the National Polytechnic School (ENP), Algiers in 2008 and 2014 respectively. She worked in several scientific research projects in UDES, the last one is about the solar smart houses. His current research interests include the optimization of photovoltaic systems especially on the application of artificial intelligence techniques in these systems. She focuses also in their research works on the development of intelligent energy management systems in the solar houses and their automation. 